\title{
Design and Implementation of the Operation Skill Training System for Elevator
}

\author{
JunfangXia ${ }^{1, \text { a }}$,Ping Tang ${ }^{1, b}$,Shirong Liu ${ }^{1, c}$,Mulin Zheng ${ }^{1, d}$ andShuai Kong ${ }^{1, e}$ \\ ${ }^{1}$ Zhejiang Provincial Special Equipment Inspection and Research Institute, Hangzhou 310020, \\ China. \\ axiajunfang123@163.com, btangpingjob@163.com, '985807608@qq.com, 'mulinzheng@126.com, \\ ekserjin@gmail.com
}

Keywords:Elevator; virtual reality technology; training

\begin{abstract}
Based on the virtual reality technology, we developed a training operation skill system for elevator by the modular design. It would be applied to assess workers for elevator. According to the country assessment outline, the system realized the functions of theory and operation skill training. In addition, it realized the simulation for elevator parts by using the SolidWorks software to model.
\end{abstract}

\section{Introduction}

With the continuous development of elevator industry, there are more and more demands for elevator professional workers to enterprise. At present, there has never been developed a professional education system for personnel training in our country. The higher education and vocational education about elevator can't meet the urgent needs of market for professional workers. The shortage of technical person has become a common problem for the enterprises which are elevator manufactures or installation and maintenance enterprises. The training equipment need big investment, it is high fault and will be upgraded frequently. All the problems will be result in improving the education costs. There is uneven quality of training. Most of enterprises organized their staff to train by themselves with the mode of 'master apprentice'. The training which is before exam to get the certificate is the use of mechanical teaching material or file teaching. It is to pass the examby teaching. The final result is that the trainee's abilities can't meet the requirements of production, and the trainee can't learn that how to solve the practice problem efficiently.

Consequently, the virtual reality technology would be applied in elevator operation training to solve these problems efficiently. Based on the virtual reality technology, our paper developed a training system for elevator operation by the technology of modeling, rendering, animating. The system could solve the problem in the elevator training, to improve the quality and efficiency of training. It was practical very much.

\section{Summary}

TSG T6001-2007 "Examination Requirements for Safety Administrator and Operators of Elevator" which government issued, present that it requires the elevator workers to exam the theory and practices. In the system, combined with the course, the examination requirements were classified, and the elevator knowledge would be presented to the user interface by the way of module. It constructed a human computer interactive learning model. According to the specific trainees, the modules which contained elevator structure, key parts and operation principle, installation technology, detection criterion and standard, foundation theory and so on were classified.

Since, the examination requirements present that it is necessary to examine the elevator parts. Considered that the parts most are mechanized, it is good to use SolidWorks because of its sheet metal design forming tools, advanced photo realistic rendering capabilities. The SolidWorks is a convenience and practical three-dimensional graphics software in industry. Designers can span multiple disciplines with ease, shortening the design cycle. 


\section{System Design}

According to the outline, it is necessary to assess the theory and skill operation for elevator safety manager and worker. For safety manager's assessment,the theory knowledge consists of foundation, professional, safety management and regulations. The skill operation consists of elevator safety management and operation.For theory's assessment, the worker is similar to safety manager. The worker contains elevator driver, installation and maintenance personal. As for skill operation, the driver's assessment consists of parts identification,emergency solution, running work and basic operation. The other's assessment contains basic operation, construction operationand Safety operation.

For the theory knowledge, the system displayed each knowledge point respectively based onknowledge memory according to outline. There are vocabulary terms displaying, sketch map, the picture andtext interpretation of functional structure. By use of multimedia technology, some of the complex structure principle and explanation would be presented through the video and animation. Such as elevator operating principle, safety clamp working principle,speed limiter working principle. The trainee can master the elevator structure and working principle quickly and clearly in the form of three-dimensional display.

For the skill operation, it is displayed mainly bymemoryknowledge and operating simulation.Memory knowledge contains common sense, management, method and so on.Dynamic operating simulation can helptrainee to understand elevator,the principle of typical parts, operating procedures, and debugging points more easily.It is conducive to strengthen trainee's ability to analyze and solve problems in practice. As shown in Table1.

Table 1 Thefunction module

\begin{tabular}{|c|c|c|c|}
\hline Function module & & Function description & Expression form \\
\hline \multirow{4}{*}{$\begin{array}{l}\text { Safety management } \\
\text { personnel }\end{array}$} & \multirow{2}{*}{ Theory } & $\begin{array}{l}\text { introduce the relevant knowledge of the } \\
\text { elevator by graphics, animation, video }\end{array}$ & $\begin{array}{l}\text { Graphics, animation, } \\
\text { video }\end{array}$ \\
\hline & & Consult the statute & PDF document \\
\hline & \multirow{2}{*}{$\begin{array}{c}\text { Skill } \\
\text { operation }\end{array}$} & $\begin{array}{c}\text { Review of the security management } \\
\text { knowledge document }\end{array}$ & $\begin{array}{c}\text { WORD、PDF } \\
\text { document }\end{array}$ \\
\hline & & Check the actual operation & Video, animation \\
\hline \multirow[b]{2}{*}{ Driver } & $\begin{array}{c}\text { Theory } \\
\text { knowledge }\end{array}$ & $\begin{array}{l}\text { introduce the system and components of } \\
\text { elevator with graphics and 3D simulation }\end{array}$ & Graphics, simulation \\
\hline & $\begin{array}{c}\text { Skill } \\
\text { operation }\end{array}$ & $\begin{array}{l}\text { Introduction operation with video, } \\
\text { graphics, animation } \\
\text { Using simulation operation process }\end{array}$ & $\begin{array}{l}\text { Video, animation, } \\
\text { Graphics, simulation }\end{array}$ \\
\hline \multirow{5}{*}{$\begin{array}{l}\text { Installation and } \\
\text { maintenance personnel }\end{array}$} & \multirow{3}{*}{$\begin{array}{l}\text { Theory } \\
\text { knowledge }\end{array}$} & $\begin{array}{c}\text { describe the basic knowledge with } \\
\text { graphics }\end{array}$ & Graphics \\
\hline & & $\begin{array}{c}\text { explain professional knowledge with } \\
\text { animation }\end{array}$ & animation \\
\hline & & Consult the statute & PDF document \\
\hline & \multirow[b]{2}{*}{$\begin{array}{c}\text { Skill } \\
\text { operation }\end{array}$} & $\begin{array}{c}\text { Provide engineering drawings and circuit } \\
\text { diagrams }\end{array}$ & $\begin{array}{l}\text { Two dimensional } \\
\text { drawing }\end{array}$ \\
\hline & & $\begin{array}{l}\text { Introduction operation with video, } \\
\text { graphics, animation } \\
\text { Using simulation operation process }\end{array}$ & $\begin{array}{l}\text { Video, animation, } \\
\text { Graphics, simulation }\end{array}$ \\
\hline
\end{tabular}

\section{Function Realization}

In the elevator parts identification module, each part need be identified according to assessment outline, as shown in Fig.1. For example, the graphic method is used for display including Control box key and Triangle lock key. The identification of elevator well contains the display of rail,rail 
bracket, cable, chain, counterpoise device and so on. The well is displayed by three dimensions. At the same time, the parts are drawn clearly, and the function of each part can be described.

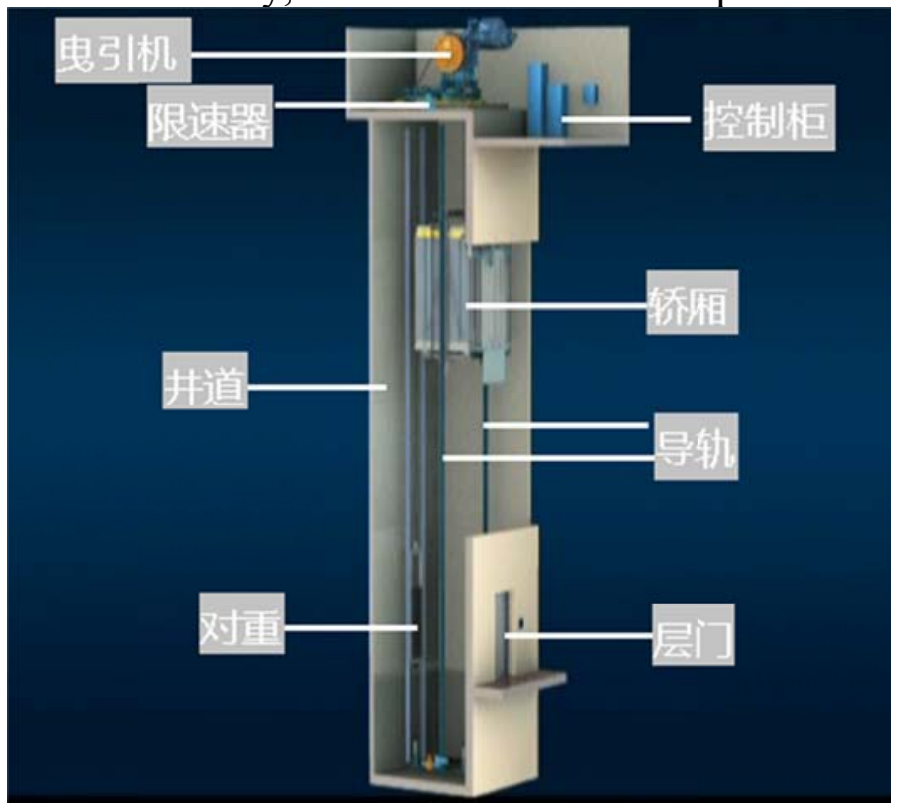

Fig. 1Elevator structure

There are some parts of location and function description in elevator car identification, as shown in Fig.2. Such as lighting switch, talk-back, fan switch, emergency stop switch, special switch, driver switch, maintenance switch, call button, layer station display, Upper and lower driving switch and so on. The parts which need be identified in machine room are control cabinet, tractor, guide wheel. Therein, the tractor's action is simulated. In elevator door, there are layer door (or car door), sill, screen, call box, door lock to be identified.

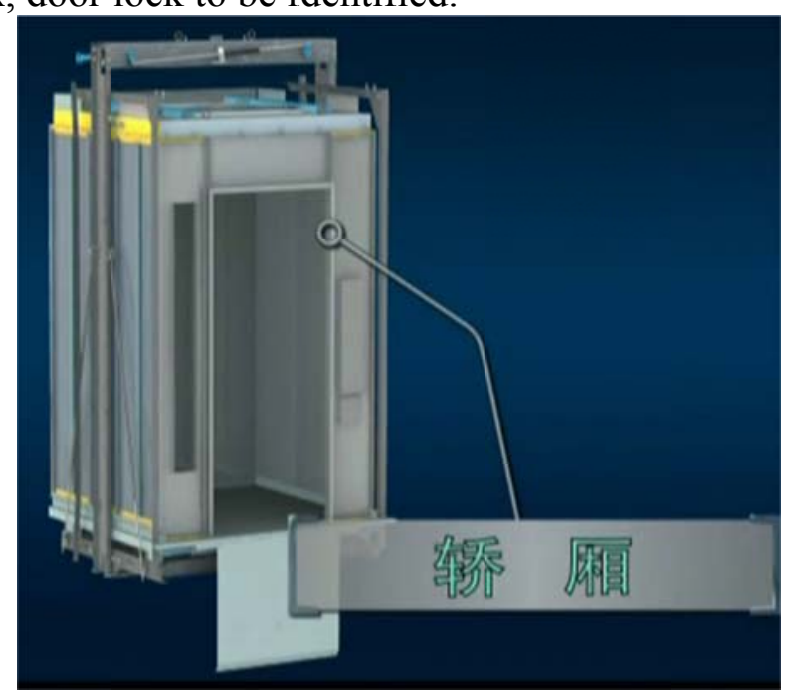

Fig. 2Elevator car

\section{Conclusion}

The paper describes the operation skill training system, which it is helpful to trainee who can be freedom to learn no matter when and where.And they will not be limited by time,space,hardware. On the basis of this study, it will be improved to join in the simulation of assessment.

\section{References}

[1] WANG Hai,XIA Yanguang, The training simulation system for elevator worker based on virtual reality technology, ELEVATOR INDUSTRY, 5(2014)71-72. 
[2] WAGN Yu, The virtual reality technology and its application in special equipment education based on Virtools, COMPUTER ENGINEERING \& SCIENCE,34(2012)97-99.

[3] DENG Xuexiong,ZHANG Yueling, ZHOU Yun, et al. Research on elevator simulation based on VRML, J. Eng. Grap. 2(2009)91-95.

[4] Conference proceedings of virtual inst.in Education, MIT June 12, (1997)163-182.

[5] YIN Qin, ZHANG Shu, PAN Bin, The application of SolidWorks in the elevator design, MECHANICAL ENGINEER,12(2008)80-81.

[6] YUN Zhou, Research and development of elevator simulation and fault analyzing based on VRML, Master,South China University of Technology, China, 2007.

[7] YIN Qin, XIAO Weiping, HE Deming, Animation of elevator safety parts mechanism action based on SolidWorks,MECHANICAL\& ELECTRICAL ENGINEERING TECHNOLOGY, 39 (2010) 85-86.

[8] ZHANG Jian, Development and research of virtual elevator group control system,Master, Sichuan University, China, 2005. 